\title{
Corrigendum: Microwave-Assisted Knoevenagel-Doebner Reaction: An Efficient Method for Naturally Occurring Phenolic Acids Synthesis
}

Louis M. M. Mouterde and Florent Allais*

Chaire ABI, AgroParisTech, CEBB, Pomacle, France

Keywords: p-hydroxycinnamic acids, ferulic acid, Sinapic acid, Caffeic acid, Coumaric acid, KnoevenagelDoebner, microwaves

\section{A Corrigendum on}

Microwave-Assisted Knoevenagel-Doebner Reaction: An Efficient Method for Naturally Occurring Phenolic Acids Synthesis

by Mouterde, L. M. M., and Allais, F. (2018). Front. Chem. 6:426. doi: 10.3389/fchem.2018.00426

In the original article, there was a mistake in Table 2. Optimization of the microwave-assisted Knoevenagel-Doebner condensation on vanillin at $50 \mathrm{~W}$. as published. The values in the Eq. of base column for lines 2 to 8 are not accurate. The corrected Table 2. Optimization of the microwave-assisted Knoevenagel-Doebner condensation on vanillin at $50 \mathrm{~W}$. appears below. The authors apologize for this error and state that this does not change the scientific conclusions of the article in any way. The original article has been updated.

\section{OPEN ACCESS}

Edited and reviewed by: Jean-Michel Lavoie, Université de Sherbrooke, Canada

*Correspondence: Florent Allais florent.allais@agroparistech.fr

Specialty section: This article was submitted to Chemical Engineering, a section of the journal

Frontiers in Chemistry

Received: 11 October 2018 Accepted: 01 November 2018 Published: 20 November 2018

Citation: Mouterde LMM and Allais F (2018) Corrigendum: Microwave-Assisted Knoevenagel-Doebner Reaction: An

Efficient Method for Naturally Occurring Phenolic Acids Synthesis.

Front. Chem. 6:568.

doi: 10.3389/fchem.2018.00568
TABLE 2 | Optimization of the microwave-assisted Knoevenagel-Doebner condensation on vanillin at $50 \mathrm{~W}$.

\begin{tabular}{|c|c|c|c|c|c|c|c|c|}
\hline Entry & Base & $\begin{array}{l}\text { Eq. of } \\
\text { base }\end{array}$ & Solvent & $\begin{array}{l}\text { Concentration } \\
\text { (M) }\end{array}$ & $\begin{array}{c}\text { Temperature } \\
\left({ }^{\circ} \mathrm{C}\right)\end{array}$ & $\begin{array}{l}\text { Time } \\
\text { (min) }\end{array}$ & $\begin{array}{c}\% \\
\text { Ferulic } \\
\text { acid }\end{array}$ & $\begin{array}{l}\text { \% Vinyl } \\
\text { Phenol }\end{array}$ \\
\hline 1 & Piperidine & 0.25 & Toluene & 0.8 & 120 & 17 & 67 & 4 \\
\hline 2 & Piperidine & 0.5 & Toluene & 1.6 & 120 & 17 & 70 & 12 \\
\hline 3 & Piperidine & 0.5 & Toluene & 1.6 & 90 & 30 & 72 & 2 \\
\hline 4 & $\mathrm{NEt}_{3}$ & 0.5 & Toluene & 1.6 & 90 & 30 & 47 & 5 \\
\hline 5 & $\mathrm{DBU}$ & 0.5 & Toluene & 1.6 & 90 & 30 & 57 & 7 \\
\hline 6 & $\mathrm{~K}_{2} \mathrm{CO}_{3}$ & 0.5 & Toluene & 1.6 & 90 & 30 & 21 & 1 \\
\hline 7 & Piperidine & 0.5 & DMF & 1.6 & 90 & 30 & 92 & 4 \\
\hline 8 & Piperidine & 0.5 & Cyrene ${ }^{\circledR}$ & 1.6 & 90 & 30 & 63 & 0 \\
\hline 9 & Piperidine & 0.125 & DMF & 1.6 & 90 & 30 & 42 & 0 \\
\hline 10 & Piperidine & 0.25 & DMF & 1.6 & 90 & 30 & 81 & 1 \\
\hline 11 & Piperidine & 0.625 & DMF & 1.6 & 90 & 30 & 81 & 17 \\
\hline
\end{tabular}

Copyright (C) 2018 Mouterde and Allais. This is an open-access article distributed under the terms of the Creative Commons Attribution License (CC BY). The use, distribution or reproduction in other forums is permitted, provided the original author(s) and the copyright owner(s) are credited and that the original publication in this journal is cited, in accordance with accepted academic practice. No use, distribution or reproduction is permitted which does not comply with these terms. 